\title{
Third Library History Seminar
}

A dedicated and enthusiastic array of library historians, antiquaries, and genealogists descended upon Tallahassee on February 8 for the Third Library History Seminar at Florida State University. Supplemented by library school students and faculty, as well as other interested persons from the area, the group sat dutifully through three days of activities, and all appeared to agree that they profited considerably from hearing some of the excellent papers and discussions, formal and informal, which were aired.

Working sessions began on Thursday with a presentation by two FSU historians of the ways in which they went about the business of historical research. The next session demonstrated historical criticism. Here two more FSU history professors served as discussants of two surprisingly good library history papers prepared by library school students Ruth Kent and Homer Walton, Jr.

Seven varied and interesting papers were presented on Friday. Kent State's Sidney Jackson opened the day with a discussion of contradictory views on books and reading among early humanists. Thomas Slavens, University of Michigan, described the circumstances under which the highly treasured Van Ess collection came to rest in the Union Theological Seminary. George S. Bobinski, University of Kentucky, closed the morning with an account of the bibliothecal importance of Andrew Carnegie's colleagues, James Bertram and Alvin S. Johnson. In the afternoon Robert V. Williams of the Georgia Department of Archives described the library and its setting in George Whitefield's Bethesda; William J. Van Beynum of the Middletown (Conn.) public library spoke on "The Book-Company of Durham;" Case Western Reserve's Clark A. Elliott pointed out the importance of the U.S. Bureau of Education to library history in that annus mirabilis 1876; and Nova's Robert Havlik told of the more recent experience of the Library Services Branch of USOE.

The best line of the show came on Saturday morning in Budd L. Gambee's (University of North Carolina) paper on "Representation of American Librarianship at World's Fairs, 1853-1876." Quoting a journalist's description of the persons attending the library conclave of 1876 , he reported that "No one could judge from their appearance that they were librarians." The last paper read was Robert C. Miller's (University of Chicago) history of the International Publishers' Association, 1896-1962.

Two special sessions were also scheduled during the three-day meeting. Lawrence Towner told the delegates on Thursday evening about his own Newberry library, and at a very fine banquet on Friday night David Kaser (Joint University Libraries) spoke on "Tom Brown's Library at Rugby."

The seminar concluded before lunch on Saturday with a summary by "the Grand old Man" of library history in America, the dean emeritus of FSU's library school, Louis Shores. All in all the conference was a good one which was well worth its designation as the third in a short but meaningful series of meetings designed to foster and encourage greater interest in the area of library history. $-D . K$. $\mathrm{\square}$

\section{ACADEMIC LIBRARY ... \\ (Continued from page 129)}

Photo Credit: Ezra Stoller

Jury Comment:

"This simple, yet elegant, project is very well detailed, well appointed, and well furnished. It presents an ingenious solution to the overall lighting scheme. The roof is pierced and beam coves allow natural light to beautifully enter the building."

Pictures of award-of-merit academic library buildings are on pages 136 and 137 .

\section{MOVING}

If you are changing your mailing address, please be sure to let ALA know at least six weeks in advance.

Important: Please send ALA both your old and new addresses plus the date you would like the change made. ( A copy of your address label clipped to your notice would help.)

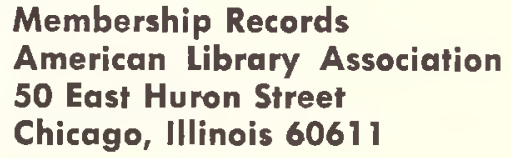

